\title{
TIM-3 is a potential prognostic marker for patients with solid tumors: A systematic review and meta-analysis
}

\author{
Yang Zhang ${ }^{1}$, Pengcheng Cai ${ }^{1}$, Tao Liang ${ }^{1}$, Lin Wang ${ }^{1,2}$ and Lihua $\mathrm{Hu}^{1}$ \\ ${ }^{1}$ Department of Clinical Laboratory, Union Hospital, Tongji Medical College, Huazhong University of Science and Technology, \\ Wuhan 430022, China \\ ${ }^{2}$ Research Center for Tissue Engineering and Regenerative Medicine, Union Hospital, Tongji Medical College, Huazhong \\ University of Science and Technology, Wuhan 430022, China \\ Correspondence to: Lihua Hu, email: lihuahu@hust.edu.cn \\ Lin Wang, email: katelinwang@126.com \\ Keywords: TIM-3, meta-analysis, solid tumor, prognostic marker, overall survival \\ Received: August 29, $2016 \quad$ Accepted: February 21, $2017 \quad$ Published: March 07, 2017 \\ Copyright: Zhang et al. This is an open-access article distributed under the terms of the Creative Commons Attribution License \\ (CC-BY), which permits unrestricted use, distribution, and reproduction in any medium, provided the original author and source \\ are credited.
}

\section{ABSTRACT}

Accumulated studies have demonstrated the important role of T cell immunoglobulinand mucin-domain-containing molecule-3 (TIM-3) in various solid tumors and indicated its correlation with patients' survival. To further verify the prognostic significance of TIM-3 in cancer patients and its correlation with tumor, we performed this meta-analysis including seven studies searched from PubMed, Web of Science, and Embase till July 2016. A total of 869 patients were used to analyze the association between TIM-3 expression and patients' overall survival (OS). The pooled results showed that higher expression of TIM-3 was significantly correlated to shorter OS ( 7 studies, HR=1.89; 95\% CI: 1.38-2.57; P< 0.001). In addition, higher TIM-3 expression was associated with advanced tumor stage ( 3 studies, III/IV vs. I/II, RR=2.02; 95\% CI: 1.45-2.81; P< 0.001 ). In conclusion, our study highlights the role of TIM-3 as a potential prognostic marker and a promising therapeutic target in solid tumors.

\section{INTRODUCTION}

$\mathrm{T}$ cell immunoglobulin- and mucin-domaincontaining molecule-3 (TIM-3) belongs to a family of receptors involved in immune-checkpoint functions. It is universally reported to play a crucial role in mediating $\mathrm{T}$ cell exhaustion both in viral infections and tumors [1-4]. The expression of TIM-3 was initially identified on $\mathrm{CD} 4 \mathrm{IFN}-\gamma$ producing cells and in cytotoxic CD8 lymphocytes in mice and humans [5]. Most recent studies have demonstrated that TIM-3 expression on $\mathrm{CD}^{+}$and $\mathrm{CD} 8^{+}$cells is closely related to $\mathrm{T}$ cell exhaustion not only in human immunodeficiency virus (HIV) and hepatitis $\mathrm{C}$ virus $(\mathrm{HCV})$, but also in cancer patients $[6,7]$.

A growing number of studies have shown that TIM3 expression is elevated in a series of solid tumors such as lung cancer [8], gastric cancer [9], colon cancer [10], hepatocellular carcinoma [11], renal cell carcinoma [12], bladder urothelial carcinoma [13], and cervical cancer
[14]. Furthermore, the increased TIM-3 level is correlated with poor survival in these tumor patients. In addition, more in-depth research illustrated that the soluble form of TIM-3 reduced the antigen-specific T cell response and downregulated the anti-tumor activity in vivo [15]. Another study revealed that blockade of TIM-3 could reverse the impaired phenotype of NK cells in patients with metastatic melanoma [16], which highlights the potential possibility of TIM-3 targeted therapy. Nevertheless, despite all the promising data proved in preclinical models, the role of TIM-3 hasn't been evaluated in clinical trials yet, maybe due to the insufficient evidence of TIM-3's role in clinical cancer patients.

Therefore, we conducted this meta-analysis, which combined all the published evidence to evaluate the prognostic implication of TIM-3 in patients with solid tumors, thereby to promote the process of genetic diagnosis for cancer and identify novel strategies targeting TIM-3. 


\section{RESULTS}

\section{Studies selection}

A total of 687 studies were identified by electronic search and 7 studies were included finally. The details of the study screening process were presented in Figure 1.

\section{Study characteristics and quality assessment}

All seven studies used immunohistochemistry techniques to assess the expression level of TIM-3. A total number of 869 participants were involved in this review. The patients were Asians diagnosed with various cancers involving: bladder urothelial carcinoma (BUC), non-small cell lung cancer (NSCLC), gastric cancer, ovarian cancer, cervical cancer, hepatitis B virus-associated hepatocellular carcinoma and clear cell renal cell carcinoma. The characteristics of the included studies were described in Table 1.

The results from the quality of included studies reveals that the selection bias exists in each included study, as each study included one type of cancer, which cannot represent the whole population of solid tumor. Three studies $[9,11$,

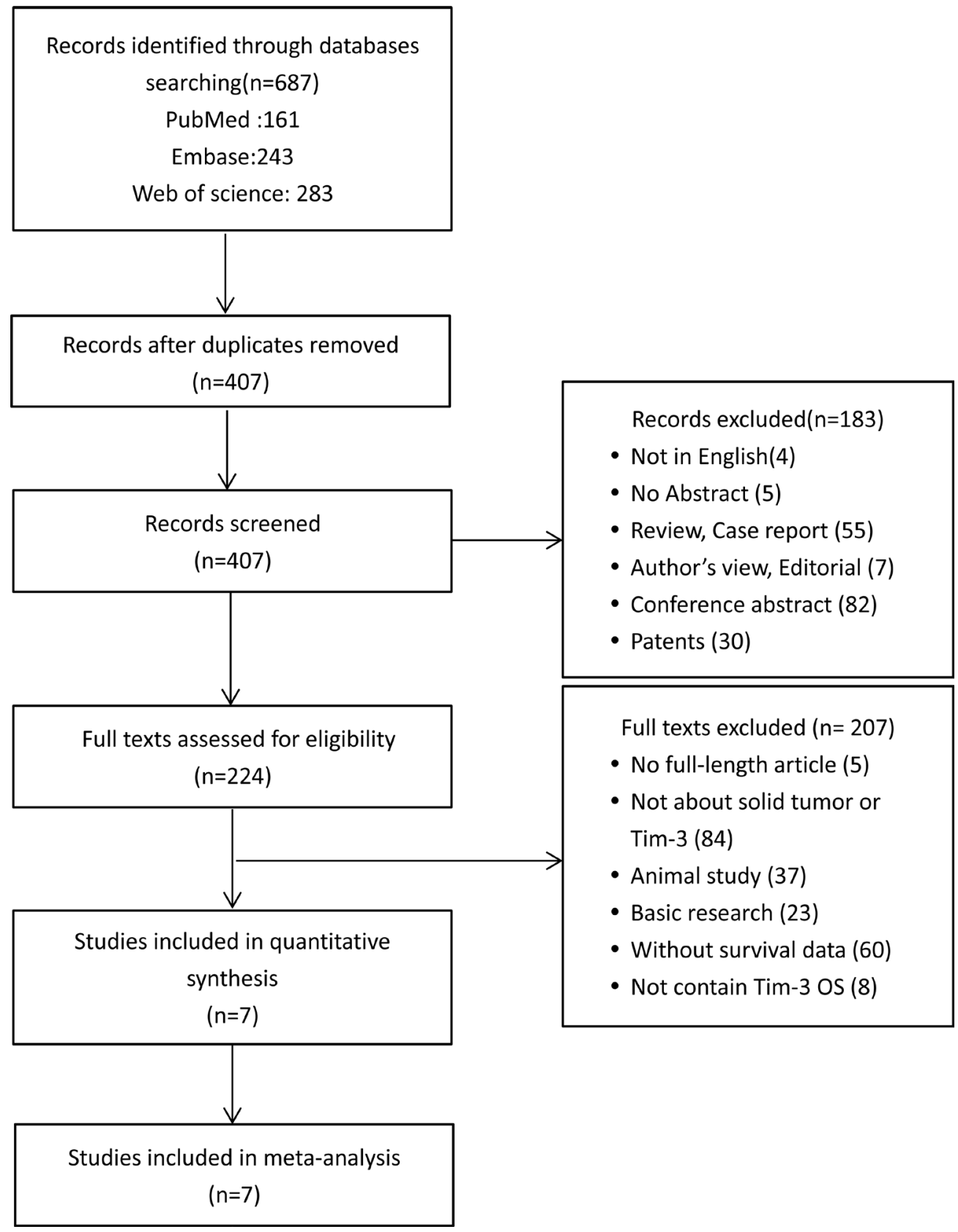

Figure 1: Flow diagram of study selection. TIM-3: T cell immunoglobulin- and mucin-domain-containing molecule-3; OS: overall survival. 
Table 1: Characteristics of studies included in the meta-analysis

\begin{tabular}{|c|c|c|c|c|c|c|c|c|c|c|}
\hline Author & Year & Country & Cancer type & $\begin{array}{l}\text { NO. of } \\
\text { patients }\end{array}$ & $\begin{array}{c}\text { Age, } \\
\text { median } \\
\text { (range) }\end{array}$ & $\begin{array}{c}\text { Male/ } \\
\text { female }\end{array}$ & $\begin{array}{c}\text { Cancer } \\
\text { stage or } \\
\text { grade }\end{array}$ & $\begin{array}{l}\text { Percentage of high } \\
\text { Tim-3 Cutoff value }\end{array}$ & $\begin{array}{l}\text { Follow-up } \\
\text { months }\end{array}$ & $\begin{array}{l}\text { HR and } \\
95 \% \mathrm{CI}\end{array}$ \\
\hline $\begin{array}{l}\text { Xuewei } \\
\text { Zhuang }\end{array}$ & 2012 & Chinese & NSCLC & 30 & $60(37-75)$ & $23 / 7$ & $\begin{array}{l}\text { TNM: } \\
\text { I-IV }\end{array}$ & $\begin{array}{c}15 / 30(50 \%),>25 \% \text { of } \\
\text { cells }\end{array}$ & $34(1-78)$ & $\mathrm{NA}^{\mathrm{a}}$ \\
\hline Meng Yang & 2015 & Chinese & $\begin{array}{l}\text { Bladder } \\
\text { Urothelial } \\
\text { Carcinoma }\end{array}$ & 100 & $65(30-81)$ & $68 / 32$ & Grade1-3 & $\begin{array}{l}50 / 100(50 \%), \\
\text { H-score } \geq 100\end{array}$ & $44(3-60)$ & NA \\
\hline $\begin{array}{l}\text { Encheng } \\
\text { Zhou }\end{array}$ & 2015 & Chinese & Colon Cancer & 201 & $65(26-90)$ & $116 / 85$ & $\begin{array}{l}\text { TNM: } \\
\text { I-IV }\end{array}$ & $\begin{array}{c}118 / 201(58.7 \%), \\
\text { HSCORE } \geq 200\end{array}$ & $61(2-103)$ & NA \\
\hline Jing Jiang & 2013 & Chinese & Gastric Cancer & 305 & $64(32-87)$ & $231 / 74$ & $\begin{array}{l}\text { TNM: } \\
\text { I-IV }\end{array}$ & $\begin{array}{c}183 / 305(60 \%) \\
\text { HSCORE }>0\end{array}$ & $40(3-135)$ & NA \\
\hline Yang Cao & 2013 & Chinese & $\begin{array}{l}\text { Cervical } \\
\text { Cancer }\end{array}$ & 43 & $39(27-67)$ & $0 / 43$ & $\begin{array}{l}\text { TNM: } \\
\text { I-IV }\end{array}$ & $\begin{array}{l}\text { 28/43(65.1\%), IRS } \\
\text { scores } 2 \text { and } 3\end{array}$ & $45.2(5-60)$ & NA \\
\hline Hang Li & 2012 & Chinese & $\begin{array}{l}\text { Hepatocellular } \\
\text { Carcinoma }\end{array}$ & 99 & $51(38-72)$ & $91 / 8$ & $\begin{array}{l}\text { TNM: } \\
\text { I-IV }\end{array}$ & $57 / 99$, NA & 36 & NA \\
\hline $\begin{array}{l}\text { Yoshihiro } \\
\text { Komohara }\end{array}$ & 2015 & Japanese & $\begin{array}{l}\text { Clear Cell } \\
\text { Renal Cell } \\
\text { Carcinoma }\end{array}$ & 91 & NA & $59 / 32$ & Grade1-4 & $\begin{array}{c}63 / 92(68.5 \%), \text { score } \\
1,2\end{array}$ & 120 & $\begin{array}{c}\text { HR:3.7 } \\
\text { CI(0.7-68) } \\
\mathrm{P}=0.12\end{array}$ \\
\hline
\end{tabular}

${ }^{a}$ NA: not available.

12] did not state whether the assessment of TIM-3 positive or high expression was evaluated by blinded pathologists, therefore the ascertainment of exposure is of some concern. For the comparability, two studies use reported unadjusted data $[12,13]$ which may induce confounding bias. Other studies $[8,10,14]$ used adjusted data (Cox multivariate analysis) to assess the prognostic value of TIM-3 for overall survival. As the prognostic outcomes are survival, so the outcome assessment is objective and the follow up is long enough for outcomes to occur (Table 2).

\section{Meta-analysis}

The prognostic value of TIM-3 in solid tumor patients' overall survival

Seven studies were included in the meta-analysis of tumor patients' OS. A fixed effect model was used to calculate the pooled $\mathrm{HR}$ and $95 \% \mathrm{CI}$, as the heterogeneity test reported a P value of 0.954 and $\mathrm{I}^{2}$ value of $0.0 \%$. The results showed that patients with higher expression of TIM-3 had significant shorter overall survival (7 studies, $\mathrm{n}=869, \mathrm{HR}=1.89 ; 95 \%$ CI: 1.38-2.57; $\mathrm{P}<0.001)$. Combing all the tumor types, the results indicated an association between TIM-3 and patients' OS (Figure 2).

\section{Association of TIM-3 with clinicopathological parameters}

In the comprehensive analysis for the role of Tim3 expression in solid tumor as a biomarker, we also investigated the association of high TIM-3 expression and clinicopathological characteristics. As shown by Table 3, TIM-3 expression had no obvious association with patients' age, sex or T stage; however, high TIM-3 expression was significantly associated with advanced TNM stage ( 3 studies, $n=331$, III/IV vs. I/II, RR=2.02; 95\% CI: $1.45-2.81 ; \mathrm{p}<0.001$ ) (Figure 3 ).

\section{Publication bias}

Begg's funnel plot and Egger's test were used to estimate the publication bias of the included literatures. The shapes of the funnel plots for the OS showed no evidence of obvious asymmetry (Figure 4), and Egger's test revealed non-significant value $(\mathrm{P}=0.134)$.

\section{Sensitivity analysis}

Sensitivity analysis was carried out to assess the influence of individual study on the synthetic results of OS. The results showed that the pooled HR was not significantly influenced after omitting any single study for the effect of TIM-3 expression on OS (Figure 5).

\section{DISCUSSION}

As far as we know, our current meta-analysis may be the only evidence evaluating the association between TIM3 expression and patients' overall survival in solid tumor. We systematically evaluated survival data for 869 patients and demonstrated a positive relationship between TIM3 high expression and poor prognosis in cancer patients. Besides, we also investigated the association between 
Table 2: The Newcastle-Ottawa Scale (NOS) quality assessment of the enrolled studies

\begin{tabular}{|c|c|c|c|c|c|c|c|c|c|}
\hline \multirow[t]{2}{*}{ Study ID } & \multicolumn{4}{|c|}{ SELECTION } & \multirow[b]{2}{*}{ 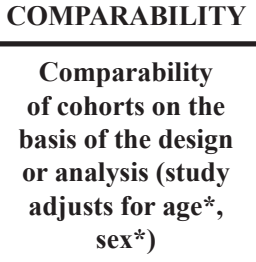 } & \multirow{2}{*}{\multicolumn{2}{|c|}{$\begin{array}{cc}\text { OUTCOME } \\
\begin{array}{c}\text { Was } \\
\text { follow- }\end{array} \\
\begin{array}{c}\text { Assessment } \\
\text { up long } \\
\text { of outcome enough for } \\
\text { outcomes } \\
\text { to occur }\end{array}\end{array}$}} & \multirow[b]{2}{*}{$\begin{array}{l}\text { Adequacy } \\
\text { of follow } \\
\text { up of } \\
\text { cohorts }\end{array}$} & \multirow[t]{2}{*}{ Total } \\
\hline & $\begin{array}{c}\text { Representativeness } \\
\text { of the exposed } \\
\text { cohort }\end{array}$ & $\begin{array}{l}\text { Selection of the } \\
\text { non-exposed } \\
\text { cohort }\end{array}$ & $\begin{array}{l}\text { Ascertainment } \\
\text { of exposure }\end{array}$ & $\begin{array}{l}\text { Demonstration } \\
\text { that outcome of } \\
\text { interest was not } \\
\text { present at start } \\
\text { of study }\end{array}$ & & & & & \\
\hline $\begin{array}{l}\text { Xuewei } \\
\text { Zhuang } \\
2012[8]\end{array}$ & - & - & $*$ & $*$ & $* *$ & $*$ & $*$ & $*$ & 7 \\
\hline $\begin{array}{l}\text { Meng } \\
\text { Yang } 2015 \\
{[13]}\end{array}$ & - & - & - & $*$ & $*$ & $*$ & $*$ & $*$ & 5 \\
\hline $\begin{array}{l}\text { Encheng } \\
\text { Zhou } 2015 \\
{[10]}\end{array}$ & - & - & $*$ & $*$ & $* *$ & $*$ & $*$ & $*$ & 7 \\
\hline $\begin{array}{l}\text { Jing Jiang } \\
2013 \text { [9] }\end{array}$ & - & - & $*$ & $*$ & $* *$ & $*$ & $*$ & $*$ & 7 \\
\hline $\begin{array}{l}\text { Yang Cao } \\
2013[14]\end{array}$ & - & - & - & $*$ & $* *$ & $*$ & * & $*$ & 6 \\
\hline $\begin{array}{l}\text { Hang Li } \\
2012 \text { [11] }\end{array}$ & - & - & - & $*$ & $* *$ & $*$ & $*$ & $*$ & 6 \\
\hline $\begin{array}{l}\text { Yoshihiro } \\
\text { Komohara } \\
2015[12]\end{array}$ & - & - & $*$ & $*$ & - & $*$ & $*$ & $*$ & 5 \\
\hline
\end{tabular}

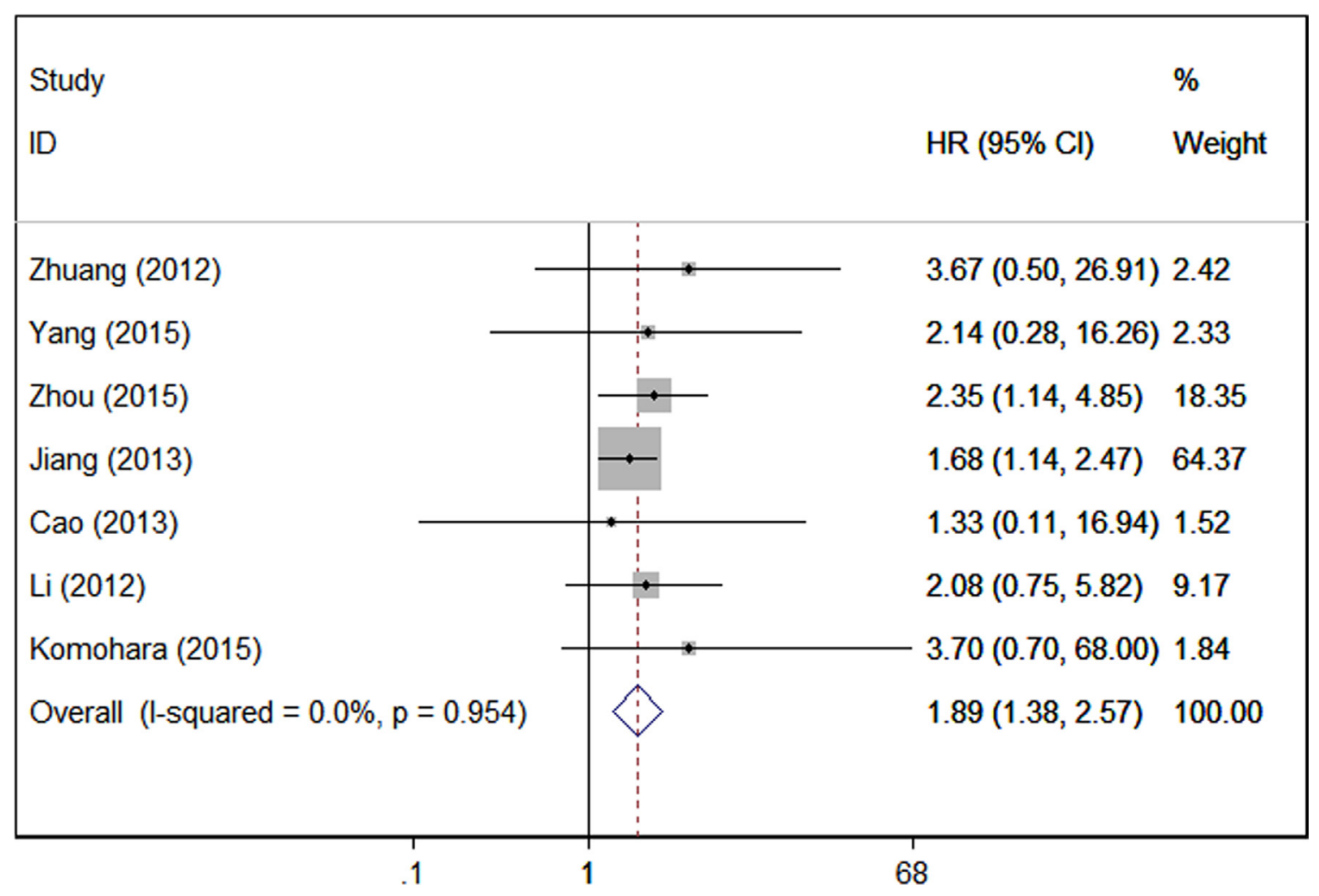

Figure 2: Forrest plots of studies evaluating TIM-3 expression level and patients' overall survival. 
Table 3: Correlation of TIM-3 expression and clinical features

\begin{tabular}{|c|c|c|c|c|c|c|c|}
\hline Variables & Cancer type & Studies & Pooled RR & $95 \% \mathrm{CI}$ & Model & $\begin{array}{c}\text { Heterogeneity } I^{2} \\
(\%)\end{array}$ & P Value \\
\hline \multirow[t]{4}{*}{$\overline{\text { Age }}$} & Overall & 3 & 0.889 & $0.678-2.605$ & fixed & 0.0 & 0.264 \\
\hline & $\begin{array}{l}\text { Non-small cell } \\
\text { lung cancers }\end{array}$ & 1 & 0.971 & $0.747-1.263$ & & & \\
\hline & $\begin{array}{l}\text { Bladder urothelial } \\
\text { carcinoma }\end{array}$ & 1 & 0.820 & $0.579-1.161$ & & & \\
\hline & Gastric cancer & 1 & 0.750 & $0.344-1.636$ & & & \\
\hline \multirow[t]{5}{*}{ Sex } & Overall & 4 & 0.976 & $0.757-1.258$ & fixed & 0.0 & 0.850 \\
\hline & $\begin{array}{l}\text { Non-small cell } \\
\text { lung cancers }\end{array}$ & 1 & 1.333 & $0.358-4.965$ & & & \\
\hline & $\begin{array}{l}\text { Bladder urothelial } \\
\text { carcinoma }\end{array}$ & 1 & 0.778 & $0.436-1.386$ & & & \\
\hline & Colon cancer & 1 & 1.055 & $0.758-1.469$ & & & \\
\hline & $\begin{array}{l}\text { Clear cell renal cell } \\
\text { carcinomas }\end{array}$ & 1 & 0.928 & $0.511-1.686$ & & & \\
\hline \multirow[t]{5}{*}{ T stage } & Overall & 4 & 2.464 & $0.104-58.422$ & random & 99.4 & 0.577 \\
\hline & $\begin{array}{l}\text { Non-small cell } \\
\text { lung cancers }\end{array}$ & 1 & 1.571 & $0.844-2.924$ & & & \\
\hline & $\begin{array}{l}\text { Bladder urothelial } \\
\text { carcinoma }\end{array}$ & 1 & 9.750 & $3.765-25.247$ & & & \\
\hline & Colon cancer & 1 & 0.976 & $0.942-1.012$ & & & \\
\hline & $\begin{array}{l}\text { Clear cell renal cell } \\
\text { carcinomas }\end{array}$ & 1 & 2.531 & $1.306-4.906$ & & & \\
\hline \multirow[t]{4}{*}{ TNM stage } & Overall & 3 & 1.654 & $0.641-4.270$ & fixed & 0.0 & $<0.001$ \\
\hline & $\begin{array}{l}\text { Non-small cell } \\
\text { lung cancers }\end{array}$ & 1 & 2.000 & $0.763-5.242$ & & & \\
\hline & Colon cancer & 1 & 2.052 & $1.419-2.967$ & & & \\
\hline & $\begin{array}{l}\text { Hepatocellular } \\
\text { carcinoma }\end{array}$ & 1 & 1.842 & $0.620-5.473$ & & & \\
\hline
\end{tabular}

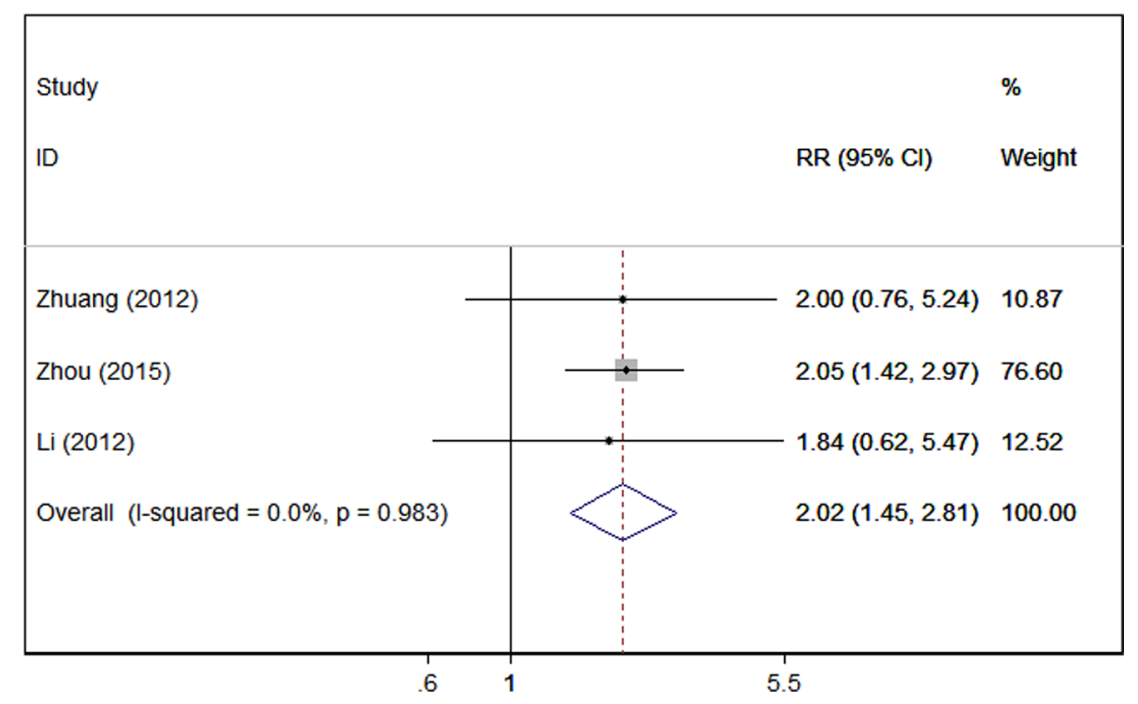

Figure 3: Forrest plots of studies evaluating TIM-3 expression and TNM stage. 
TIM-3 expression and clinicopathological characteristics. Results support that TIM-3 high expression is significantly correlated with advanced tumor stage, which indicates that TIM-3 probably participates in tumor progression and finally affects tumor prognosis.

It has been demonstrated that $\mathrm{T}$ cell exhaustion could promote tumorigenesis and tumor progression in various cancers [17], and TIM-3 is one of the most important molecules that mediate $\mathrm{T}$ cell exhaustion [18]. Accumulating evidences have revealed that TIM3 contributed to tumor-initiating and tumor-promoting activities [19, 20]. Huang et al found that TIM-3 could facilitate the onset, growth and dissemination of lymphoma by suppressing activation of $\mathrm{CD}^{+} \mathrm{T}$ cell through the

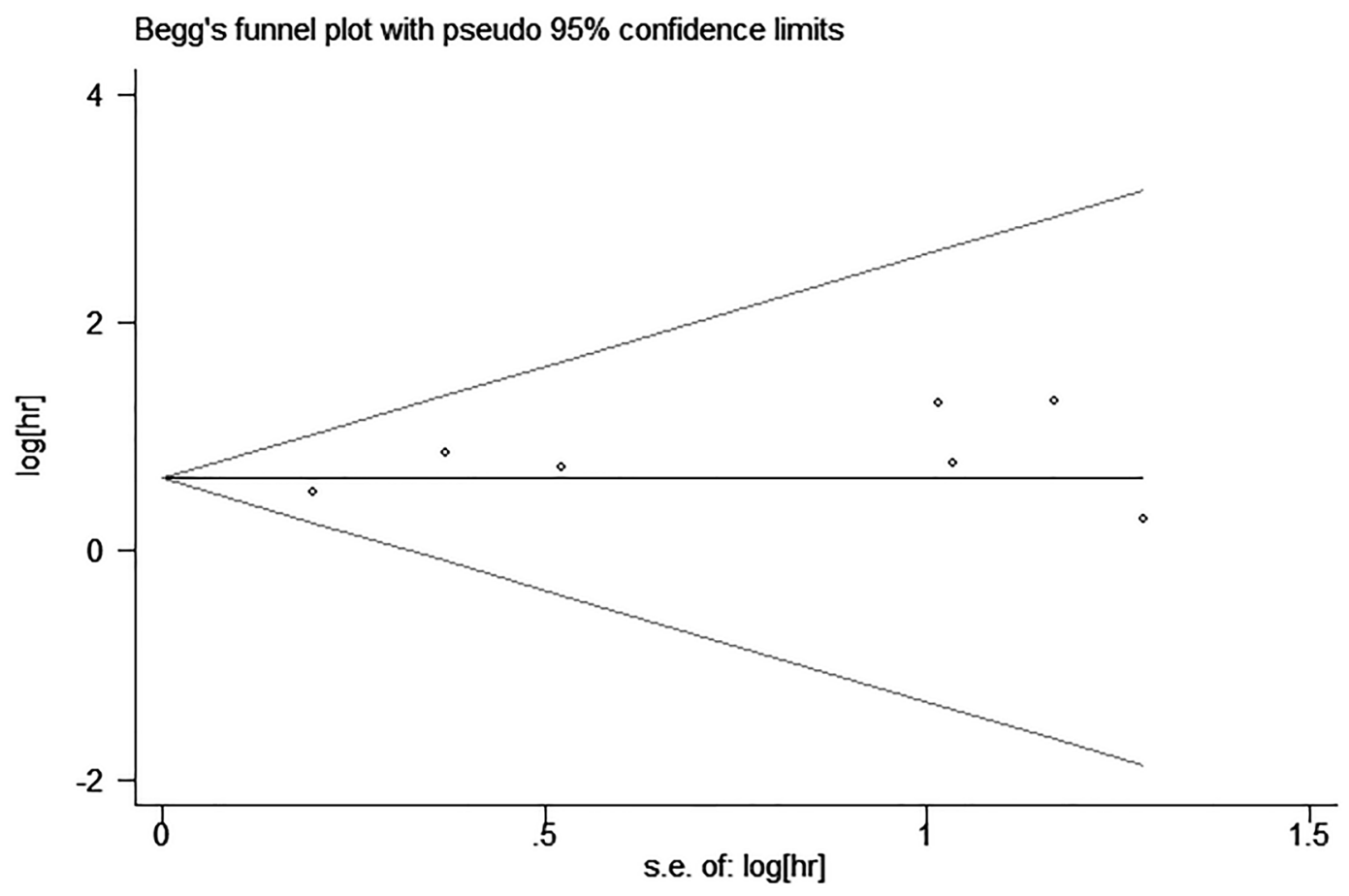

Figure 4: Begg's funnel plot estimating the publication bias of the included literatures.

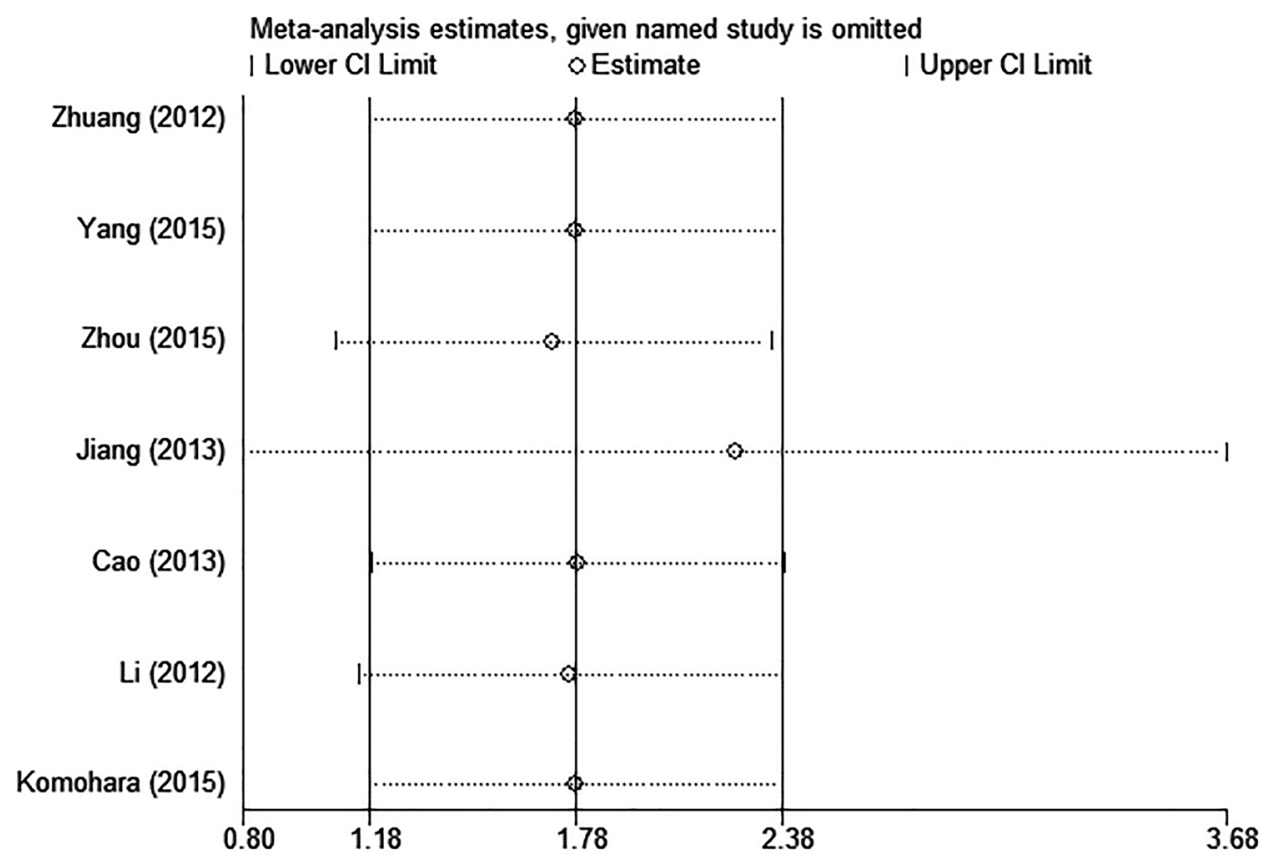

Figure 5: Sensitivity analysis of this meta-analysis. 
interleukin-6-STAT3 pathway [21]. Our lab recently identified that $\mathrm{TIM}-3^{+} \mathrm{CD} 8^{+} \mathrm{T}$ cell have impaired ability of IFN- $\gamma$ production which inhibited the cytotoxic activity of functional T cells [22]. Another study conducted by YuHwa Huang found that administration of anti-mTIM-3 to mouse models with colon cancer delayed tumor growth. Moreover, TIM-3 blockade was associated with enhanced IFN- $\gamma$ production, which indicated restoration of $\mathrm{T}$ cell function [23]. All these studies illustrated that TIM-3 may promote cancer progression through IL-6/STAT3 pathway or inhibiting IFN- $\gamma$ production of effective T cells against tumor cells, exhibiting the function as a tumor-promoting role.

In the case of immunosuppressive prognostic markers, there are others like CTLA-4 (cytotoxic T-lymphocyte antigen-4), LAG3 (Lymphocyte-activation gene 3) and PD-1(programmed death-1) have been identified as well as TIM-3 [24]. Furthermore, some of them have been applicated in the immunotherapy for malignant tumors $[25,26]$. Unfortunately, there are no optimal targets so far, although the PD-1 blockage has shown some encouraging effects and has been implicated in some clinical trials, however, the benefits and improved prognosis for cancer patients remain unsatisfactory [27]. Our study implies that TIM-3 may be a prognostic marker of patients' survival with solid tumors, and high expression of TIM-3 may correlate with advanced tumor stage. These findings reveal that TIM-3 may be an emerging target in cancer therapy. Interestingly, there are several preclinical studies which show that combined targeting of TIM-3 and PD-1 pathways is more effective in controlling tumor growth than targeting either pathway alone [3]. It is promising to see the responses of combined immunotherapies.

In the meanwhile, there are some limitations for this paper as well. First of all, all the enrolled participants were Asians and could not represent the whole population; secondly, some of the studies are in small scale, which include patients less than 40; thirdly, the quality of the included studies is with selection bias, as each study included only one type of cancer, which also exhibiting the urgency for more studies with larger sample size regarding this.

In conclusion, TIM-3 seems not merely a valuable prognostic marker but also a promising therapeutic target for solid tumors. Due to the sparse data, more studies regarding TIM-3 are still required.

\section{MATERIALS AND METHODS}

\section{Literature search}

We searched for papers published in PubMed, Web of Science and Embase on July 4, 2016. The following keywords were used to perform the search: "HAVCR2/Tcell immunoglobulin and mucin domain containing 3",
"TIM-3", "T-cell Ig and mucin domain 3", "hepatitis A virus cellular receptor 2", "cancer", "tumor", "carcinoma", "neoplasm", "prognosis", "survival", "mortality" and "death".

Three review authors screened the studies with the following inclusion criteria: i) studies investigating the association of TIM-3 with prognostic outcomes in solid tumor; ii) The study designs were cross-sectional study, cohort study or case-control study; iii) The interested prognostic outcomes include overall survival and tumor progression (tumor stage and histological grade); iv) The study was published in English [28]. We will exclude animal studies and studies with the length of follow-up less than 3 years. Studies that are not available in full text will also be excluded. Any disagreement between the three authors will be resolved by consensus.

\section{Data collection and quality assessment}

Three investigators independently extracted the data from eligible studies using a predefined form. The collected data included the name of first author, publication year, patients' country of origin, tumor type, number of patients, age, sex, cancer stage or grade, detection method for TIM-3 expression, percentage exhibiting high TIM-3 expression and the corresponding cutoff value, median follow-up months, outcome, HR and 95\% CI of high TIM3 expression group versus low.

For studies that presented only Kaplan-Meier curves, Engauge Digitizer (version 4.1) was used to extract the survival data. The estimated HRs and 95\% CIs were calculated by Tierney's method [28]. Three review authors independently assessed the quality of included studies by using Newcastle-Ottawa Quality Assessment Scale (NOS). Three domains were evaluated including selection of participants, comparability, and ascertainment of outcome.

\section{Statistical analysis}

Stata version 14.0 (Stata Corporation, College Station, TX, USA) was used to carry out the statistical analysis. Pooled HRs and 95\% CIs for OS were used to assess the association between TIM-3 expression and overall survival. In addition, RRs and their 95\% CIs were used to assess the correlation between TIM-3 expression and the clinicopathological features of each solid tumor. Heterogeneity was assessed by the $\mathrm{I}^{2}$ value derived from $Q$ test [29] coupled with a P value from Chi square test. We considered a $P$ value of less than 0.10 and $\mathrm{I}^{2}>50 \%$ as significant heterogeneity. Fixed effect model was initially applied to combine the estimates of effect, while a substantial heterogeneity between studies was observed and the source of heterogeneity was identified, otherwise a random effects model was used to combine the data [30]. 


\section{Publication bias and sensitivity analysis}

Publication bias was tested using Begg's funnel plot and the Egger's test [31]. If the funnel plot is asymmetric and the Egger's test reported a P value of less than 0.05, publication bias is deemed to probably exist.

Meanwhile, we performed the sensitivity analysis for overall survival by omitting each study to assess the influence of individual study on the whole meta-analysis.

\section{ACKNOWLEDGMENTS}

Author contributions: Yang Zhang: concept and design, data collection, data analysis, manuscript draft. Pengcheng Cai: concept, data collection, critical revision. Tao Liang: data collection, critical revision. Lihua $\mathrm{Hu}$ and Lin Wang: funding and study supervision.

\section{CONFLICTS OF INTEREST}

The authors declare no conflicts of interest.

\section{GRANT SUPPORT}

This study is supported by the National Natural Science Foundation of China (NO.81372259) and in parts by the National Natural Science Foundation of China (NO.81200020).

\section{REFERENCES}

1. Sanchez-Fueyo A, Tian J, Picarella D, Domenig C, Zheng XX, Sabatos CA, Manlongat N, Bender O, Kamradt T, Kuchroo VK, Gutierrez-Ramos JC, Coyle AJ, Strom TB. Tim-3 inhibits $\mathrm{T}$ helper type 1-mediated auto- and alloimmune responses and promotes immunological tolerance. Nat Immunol. 2003; 4:1093-1101.

2. Sabatos CA, Chakravarti S, Cha E, Schubart A, SanchezFueyo A, Zheng XX, Coyle AJ, Strom TB, Freeman GJ, Kuchroo VK. Interaction of Tim-3 and Tim-3 ligand regulates $\mathrm{T}$ helper type 1 responses and induction of peripheral tolerance. Nat Immunol. 2003; 4:1102-1110.

3. Sakuishi K, Apetoh L, Sullivan JM, Blazar BR, Kuchroo VK, Anderson AC. Targeting Tim-3 and PD-1 pathways to reverse $\mathrm{T}$ cell exhaustion and restore anti-tumor immunity. The Journal of experimental medicine. 2010; 207:2187-2194.

4. Hervas-Stubbs S, Soldevilla MM, Villanueva H, Mancheno U, Bendandi M, Pastor F. Identification of TIM3 2'-fluoro oligonucleotide aptamer by HT-SELEX for cancer immunotherapy. Oncotarget. 2016; 7:4522-4530. doi: 10.18632/oncotarget.6608.

5. Monney L, Sabatos CA, Gaglia JL, Ryu A, Waldner H, Chernova T, Manning S, Greenfield EA, Coyle AJ, Sobel RA, Freeman GJ, Kuchroo VK. Th1-specific cell surface protein Tim-3 regulates macrophage activation and severity of an autoimmune disease. Nature. 2002; 415:536-541.

6. Golden-Mason L, Palmer BE, Kassam N, TownshendBulson L, Livingston S, McMahon BJ, Castelblanco N, Kuchroo V, Gretch DR, Rosen HR. Negative immune regulator Tim-3 is overexpressed on T cells in hepatitis C virus infection and its blockade rescues dysfunctional CD4+ and CD8+ T cells. J Virol. 2009; 83:9122-9130.

7. Xu B, Yuan L, Gao Q, Yuan P, Zhao P, Yuan H, Fan H, Li T, Qin P, Han L, Fang W, Suo Z. Circulating and tumor-infiltrating Tim-3 in patients with colorectal cancer. Oncotarget. 2015; 6:20592-20603. doi: 10.18632/ oncotarget.4112.

8. Zhuang X, Zhang X, Xia X, Zhang C, Liang X, Gao L, Zhang X, Ma C. Ectopic expression of TIM-3 in lung cancers: a potential independent prognostic factor for patients with NSCLC. Am J Clin Pathol. 2012; 137:978-985.

9. Jiang J, Jin MS, Kong F, Cao D, Ma HX, Jia Z, Wang YP, Suo J, Cao X. Decreased galectin-9 and increased Tim-3 expression are related to poor prognosis in gastric cancer. PLoS One. 2013; 8:e81799.

10. Zhou E, Huang Q, Wang J, Fang C, Yang L, Zhu M, Chen J, Chen L, Dong M. Up-regulation of Tim-3 is associated with poor prognosis of patients with colon cancer. Int J Clin Exp Pathol. 2015; 8:8018-8027.

11. Li H, Wu K, Tao K, Chen L, Zheng Q, Lu X, Liu J, Shi L, Liu C, Wang G, Zou W. Tim-3/galectin-9 signaling pathway mediates T-cell dysfunction and predicts poor prognosis in patients with hepatitis B virus-associated hepatocellular carcinoma. Hepatology. 2012; 56:1342-1351.

12. Komohara Y, Morita T, Annan DA, Horlad H, Ohnishi K, Yamada S, Nakayama T, Kitada S, Suzu S, Kinoshita I, Dosaka-Akita H, Akashi K, Takeya M, et al. The Coordinated Actions of TIM-3 on Cancer and Myeloid Cells in the Regulation of Tumorigenicity and Clinical Prognosis in Clear Cell Renal Cell Carcinomas. Cancer Immunol Res. 2015; 3:999-1007.

13. Yang M, Yu Q, Liu J, Fu W, Cao Y, Yu L, Shao S, Wang X, Niu H, Wang Y. T-cell immunoglobulin mucin-3 expression in bladder urothelial carcinoma: Clinicopathologic correlations and association with survival. J Surg Oncol. $2015 ; 112: 430-435$.

14. Cao Y, Zhou X, Huang X, Li Q, Gao L, Jiang L, Huang M, Zhou J. Tim-3 expression in cervical cancer promotes tumor metastasis. PLoS One. 2013; 8:e53834.

15. Geng H, Zhang GM, Li D, Zhang H, Yuan Y, Zhu HG, Xiao $\mathrm{H}$, Han LF, Feng ZH. Soluble form of T cell Ig mucin 3 is an inhibitory molecule in T cell-mediated immune response. J Immunol. 2006; 176:1411-1420.

16. da Silva IP, Gallois A, Jimenez-Baranda S, Khan S, Anderson AC, Kuchroo VK, Osman I, Bhardwaj N. Reversal of NK-cell exhaustion in advanced melanoma by Tim-3 blockade. Cancer Immunol Res. 2014; 2:410-422. 
17. Yan J, Zhang Y, Zhang JP, Liang J, Li L, Zheng L. Tim-3 expression defines regulatory $\mathrm{T}$ cells in human tumors. PLoS One. 2013; 8:e58006.

18. Anderson AC. Tim-3, a negative regulator of anti-tumor immunity. Curr Opin Immunol. 2012; 24:213-216.

19. Kikushige Y, Shima T, Takayanagi S, Urata S, Miyamoto T, Iwasaki H, Takenaka K, Teshima T, Tanaka T, Inagaki Y, Akashi K. TIM-3 is a promising target to selectively kill acute myeloid leukemia stem cells. Cell Stem Cell. 2010; 7:708-717.

20. Jan M, Chao MP, Cha AC, Alizadeh AA, Gentles AJ, Weissman IL, Majeti R. Prospective separation of normal and leukemic stem cells based on differential expression of TIM3, a human acute myeloid leukemia stem cell marker. Proc Natl Acad Sci U S A. 2011; 108:5009-5014.

21. Huang X, Bai X, Cao Y, Wu J, Huang M, Tang D, Tao S, Zhu T, Liu Y, Yang Y, Zhou X, Zhao Y, Wu M, et al. Lymphoma endothelium preferentially expresses Tim-3 and facilitates the progression of lymphoma by mediating immune evasion. The Journal of experimental medicine. 2010; 207:505-520.

22. Zhang Y, Cai P, Li L, Shi L, Chang P, Liang T, Yang Q, Liu Y, Wang L, Hu L. Co-expression of TIM-3 and CEACAM1 promotes $\mathrm{T}$ cell exhaustion in colorectal cancer patients. Int Immunopharmacol. 2017; 43:210-218.

23. Huang YH, Zhu C, Kondo Y, Anderson AC, Gandhi A, Russell A, Dougan SK, Petersen BS, Melum E, Pertel T, Clayton KL, Raab M, Chen Q, et al. CEACAM1 regulates TIM-3-mediated tolerance and exhaustion. Nature. 2015; 517:386-390.
24. Ascierto PA, Atkins M, Bifulco C, Botti G, Cochran A, Davies M, Demaria S, Dummer R, Ferrone S, Formenti S, Gajewski TF, Garbe C, Khleif S, et al. Future perspectives in melanoma research: meeting report from the "Melanoma Bridge": Napoli, December 3rd-6th 2014. J Trans1 Med. 2015; $13: 374$.

25. Ribas A. Tumor immunotherapy directed at PD-1. The New England journal of medicine. 2012; 366:2517-2519.

26. Hodi FS, O'Day SJ, McDermott DF, Weber RW, Sosman JA, Haanen JB, Gonzalez R, Robert C, Schadendorf D, Hassel JC, Akerley W, van den Eertwegh AJ, Lutzky $\mathrm{J}$, et al. Improved survival with ipilimumab in patients with metastatic melanoma. The New England journal of medicine. 2010; 363:711-723.

27. Moon EK, Wang LC, Dolfi DV, Wilson CB, Ranganathan R, Sun J, Kapoor V, Scholler J, Pure E, Milone MC, June $\mathrm{CH}$, Riley JL, Wherry EJ, et al. Multifactorial T-cell hypofunction that is reversible can limit the efficacy of chimeric antigen receptor-transduced human T cells in solid tumors. Clin Cancer Res. 2014; 20:4262-4273.

28. Tierney JF, Stewart LA, Ghersi D, Burdett S, Sydes MR. Practical methods for incorporating summary time-to-event data into meta-analysis. Trials. 2007; 8:16.

29. Lau J, Ioannidis JP, Schmid CH. Quantitative synthesis in systematic reviews. Ann Intern Med. 1997; 127:820-826.

30. DerSimonian R, Laird N. Meta-analysis in clinical trials. Control Clin Trials. 1986; 7:177-188.

31. Egger M, Davey Smith G, Schneider M, Minder C. Bias in meta-analysis detected by a simple, graphical test. BMJ. 1997; 315:629-634. 